\title{
Zinc supplementation improves heme biosynthesis in rats exposed to lead
}

\author{
Budi Santosa*, Hertanto Wahyu Subagio**, Lisyani Suromo***, \\ and Henna Rya Sunoko****
}

\begin{abstract}
BACKGROUND
Lead acetate $(\mathrm{Pb})$ inhibits heme biosynthesis through inhibition of $\delta$ aminolevulinic acid dehydrogenase $(\delta$-ALAD), copro porphyrinogen oxidase, and ferro chelatase. Zinc supplementation increases lead-binding metallothionein proteins. The purpose of this study was to find evidence that zinc supplementation prior to lead exposure improves heme biosynthesis in rats.
\end{abstract}

\section{METHODS}

This was a randomized post-test only control-group design study involving 28 rats assigned to 4 groups (1 control and 3 treatment groups). The treatment groups were supplemented with zinc at doses of 0.2, 0.4, and $0.8 \mathrm{mg}$ daily by gavage for 3 weeks. From week 4 to 13, all groups were exposed to lead $0.5 \mathrm{~g} / \mathrm{kg} \mathrm{BW} /$ day by gavage. At the end of week $13, \delta$ ALAD, erythrocyte protoporphyrin (EPP), and heme concentrations were determined by means of ELISA. One-way ANOVA, followed by Bonferroni's test was used to analyse the data.

\section{RESULTS}

Mean $\delta$-ALAD concentrations decreased from the control group down to treatment group $3(0.24 \pm 0.20 ; 0.15 \pm 0.15 ; 0.12 \pm 0.11 ; 0.05 \pm 0.06 \mathrm{ng} /$ mean per unit). Mean EPP concentrations decreased from the control group down to treatment group $3(1.96 \pm 0.50 ; 1.24 \pm 0.24 ; 1.03 \pm 0.05$; $0.62 \pm 0.16 \mathrm{ng} / \mathrm{mL})$. Mean heme concentrations increased from the control group up to treatment group $3(8.07 \pm 2.64 ; 10.11 \pm 2.27 ; 10.04 \pm 1.65$; $11.41 \pm 2.58 \mu \mathrm{M})$. ANOVA followed by Bonferroni showed that EPP concentrations differed significantly between the control group and treatment group $3(\mathrm{p}=0.00)$.

\section{CONCLUSION}

Zinc supplementation prior to lead exposure improves heme biosynthesis in rats exposed to lead.

Keywords: Zinc, $\delta$-ALAD, EPP, heme
*Health Analyst, Faculty of Nursing and Health, Muhammadiyah

University, Semarang

***Department of Nutrition,

Dr. Kariadi Hospital/ Diponegoro University, Semarang

***Department of Pathology,

Dr. Kariadi Hospital/ Diponegoro University, Semarang ****Department of Pharmacy,

Dr. Kariadi Hospital/

Diponegoro University, Semarang

Correspondence

Dr. Budi Santosa, S.KM, M.Si.Med

Health Analyst,

Faculty of Nursing and Health,

Muhammadiyah University,

Semarang

Jl. Kedungmundu Raya 18 Semarang

Mobile: +6281805867211

Email:

budisantosa.unimus@gmail.com

Univ Med 2015;34:3-9

DOI: 10.18051/UnivMed.2016.v35.3-9 pISSN: 1907-3062 / eISSN: 2407-2230

This open access article is distributed under a Creative Commons Attribution-Non Commercial-Share Alike 4.0 International License 


\section{Suplementasi seng memperbaiki biosintesis heme pada tikus yang terpajan $\mathrm{Pb}$}

\section{ABSTRAK}

\section{LATAR BELAKANG}

Plumbum $(\mathrm{Pb})$ asetat menghambat proses biosintesis heme melalui inhibisi enzim $\delta$-ALAD, coproporfirinogen oksidase, ferrokhelatase. Suplementasi seng meningkatkan protein metallothionein yang mengikat Pb. Tujuan penelitian ini untuk membuktikan suplementasi seng sebelum pajanan $\mathrm{Pb}$ memperbaiki proses biosintesis heme pada tikus.

\section{METODA}

Penelitian eksperimental dengan rancangan pra-pasca dengan menggunakan kontrol dilakukan pada 28 ekor tikus yang secara acak sederhana dibagi menjadi 4 kelompok yaitu 1 kelompok kontrol dan 3 kelompok perlakuan. Pada kelompok perlakuan disuplementasi seng 0,2; 0,4; 0,8 mg setiap hari melalui sonde sampai minggu ke-3, awal minggui ke-4 kelompok kontrol dan perlakuan dipajan $\mathrm{Pb} 0,5 \mathrm{gr} / \mathrm{kg}$ BB/hari melalui sonde sampai minggu ke-13. Akhir minggu ke-13 diperiksa $\delta$-ALAD, EPP, heme menggunakan ELISA. Analisa data menggunakan Kruskal Wallis, kadar EPP dan heme dengan uji one way ANOVA, dilanjutkan Bonferroni.

HASIL

Rerata $\delta$-ALAD menurun mulai kelompok kontrol sampai perlakuan ke-3 $(0,24 \pm 0,20 ; 0,15 \pm 0,15 ; 0,12 \pm 0,11$; $0,05 \pm 0,06$ ng rerata per unit). Rerata EPP menurun dari kelompok kontrol sampai perlakuan ke-3 (1,96 $\pm 0,50$; $1,24 \pm 0,24 ; 1,03 \pm 0,05 ; 0,62 \pm 0,16 \mathrm{ng} / \mathrm{mL})$. Rerata heme meningkat dari kelompok kontrol sampai perlakuan ke$3(8,07 \pm 2,64 ; 10,11 \pm 2,27 ; 10,04 \pm 1,65 ; 11,41 \pm 2,58 \mu M)$. Uji ANOVA diteruskan Bonferroni menunjukkan EPP berbeda bermakna antara kelompok kontrol dengan ke-3 kelompok perlakuan $(p=0,00)$.

\section{KESIMPULAN}

Suplementasi seng sebelum pajanan Pb mampu memperbaiki biosisntesis pada tikus terpajan Pb.

Kata kunci: Seng, $\delta-A L A D, E P P$, dan heme

\section{INTRODUCTION}

Health problems may have various causes; one of these are heavy metals such as lead, which is a hazardous air pollutant. The environment can be polluted by lead through increased human acitivities, such as mining, smelting, combustion of gasoline, and the use of lead for commercial purposes. ${ }^{(1)}$ Some of the main sources of lead poisoning are vegetables, batteries, paints, cosmetics, jewelry, toys, gasoline, and others. In West and Central Java the increasing use of phosphate fertilizers, pesticides, and herbicides have the potential to increase lead exposure. The study conducted by Shah F et al. ${ }^{(2)}$ showed that in general anemia occurs in children between 15 years old, who have higher lead levels as compared with children without anemia. Among children with blood lead levels of $\geq 10 \mu \mathrm{g} / \mathrm{dL}$ there are 2.87-fold more anemia cases in comparison with children with blood lead levels of $<10 \mu \mathrm{g} / \mathrm{dL}$. $^{(3)}$

Lead intoxication may occur through inhalation, ingestion of contaminated foods and drinks, and transdermally. ${ }^{(4)}$ Lead accumulates in the mitochondria, resulting in the predominant 
effects of lead, i.e. abnormal heme biosynthesis and hematopoiesis. ${ }^{(5)}$ Lead binds and inhibits the sulfhydryl-rich enzymes involved in heme biosynthesis, i.e. $\delta$-aminolevulinic acid dehydrogenase ( $\delta$-ALAD) in the cytosol, and coproporphyrinogen oxidase and ferrochelatase in the mitochondria. ${ }^{(6)}$ The inhibition of these enzymes in heme biosynthesis as a result of lead exposure occurs at the starting point, at midpoint, and at the endpoint of heme biosynthesis. DeltaALAD is the initial enzyme inhibited by lead. Inhibition of $\delta$-ALAD prevents the conversion of $\delta$-aminolevulinic acid ( $\delta$-ALA) into porphobilinogen $(\mathrm{PBG})$, causing increased $\delta$ ALA and $\delta$-ALAD concentrations in the blood. The enzyme inhibited at midpoint of heme biosynthesis is coproporphyrinogen oxidase, resulting in increased coproporphyrinogen concentrations. The last enzyme inhibited by lead in heme biosynthesis is ferrochelatase, causing increased protoporphyrin concentrations in the erythrocytes (free erythrocyte protoporphyrin/ EPP). ${ }^{(7)}$ These abnormalities of heme biosynthesis result in a reduction in heme concentrations, leading to decreased hemoglobin concentrations and anemia.

Various attempts have been made to treat lead intoxication, such as the use of EDTA as chelating agent. ${ }^{(8)}$ A chelating agent binds lead to form a polar (hydrophilic) complex that is excreted from the body through the kidneys. According to studies that have been conducted on the use of EDTA, this is a therapeutic or curative agent. However, EDTA treatment is far from maximal, and it is administered intravenously. Therefore preventive agents should be studied to reduce lead toxicity, one of these being metallothionein proteins, since these play important roles in poisoning by heavy metals, including lead. ${ }^{(9)}$ Metallothioneins are rich in sulfhydryl groups, which form covalent bonds with heavy metals such as lead. Studies on metallothioneins have found correlations with zinc levels in the body. ${ }^{(10)}$ The study by Santosa et al. ${ }^{(11)}$ showed that zinc supplementation in stepwise increasing doses, i.e. at $0.2 \mathrm{mg}, 0.4 \mathrm{mg}$, and $0.8 \mathrm{mg}$ daily to rats (Rattus norvegicus) is capable of increasing metallothioneins. These doses have been calculated by taking a conversion factor from humans to rats into consideration. Preventive zinc supplementation has been proven to enhance hematopoesis by reducing basophilic stippling and hematocrit values in lead-exposed rats. ${ }^{(12)}$

The mechanism of the prevention of lead intoxication by zinc through heme biosynthesis is by blocking enzyme action, competition between lead and zinc, and covalent bonding. The blocking mechanism is due to the binding of lead to enzyme/protein active groups, thus inactivating the enzyme. Competition between lead and zinc atoms may occur for the metallothionein sulfhydryl groups. For each bond, the higher the cationic charge of the metal, the stronger the bond. The nearer the metal is to the noble metals the stronger its affinity. In the periodic system of elements, lead belongs to period VII and zinc to period IV. Therefore, the cationic charge of lead is greater than that of zinc, favoring lead in the competition for the metallothionein sulfhydryl groups. ${ }^{(13)}$ The covalent bonding of $\mathrm{Pb}^{2+}$ with the metallothionein sulfhydryl groups is stable and irreversible. The formation of irreversible covalent bonds between lead and metallothionein causes heme biosynthesis to be disturbed by lead exposure. Therefore zinc supplementation should be studied as a preventive alternative against inhibition of heme biosynthesis by lead exposure. The aim of this study was to evaluate the effect of zinc supplementation on heme biosynthesis in lead-exposed rats.

\section{METHODS}

\section{Study design}

The present study was carried out according to an experimental randomized post- test only control-group design. The time period from selection of experimental animals and their housing up to the interventions was 100 days, the study being conducted between December 
2012 and March 2013. The study took place in the Integrated Research and Testing Laboratory (Laboratorium Penelitian dan Pengujian Terpadu, LPPT), Gadjah Mada University, Yogyakarta.

\section{Experimental animals}

The experimental animals used were 2815 week old male black rats (Rattus norvegicus. The sampled size was determined by means of the formula:

$$
\text { Sample size }=(\mathrm{t}-1)(\mathrm{r}-1) \geq 15
$$

where $t=$ number of groups, $r=$ number of experimental animals per treatment group. The study used 3 treatment groups and and 1 control group, so that $\mathrm{t}=4,(4-1)(\mathrm{r}-1) \geq 15, \mathrm{r} \geq 6$. The number of rats used was 6 per group ( 3 treatment groups and 1 control group) so that total sample size to be used in this study was 24 . To the number of rats per group, one animal was added as reserve, in anticipation of deaths, so that the total sample size comprised 28 rats.

\section{Zinc supplementation}

Zinc supplementtion was administered to the treatment groups in stepwise increasing doses of $0.2,0.4$, and $0.8 \mathrm{mg} /$ day by gavage, whereas the control group did not receive zinc supplementation. The supplementation period was from the first week to the third week. The 7 animals per group were assigned by simple random sampling. ${ }^{(13)}$

\section{Lead exposure}

Lead exposure was by administration of $0.5 \mathrm{~g} / \mathrm{kgBW} /$ day (acute dose) for 10 weeks, from the third week to the thirteenth week. The amount of lead exposure was based on a previous study on the effect of lead acetate administration to Rattus norvegicus. ${ }^{(14)}$ Lead exposure was given in the form of a solution of $0.5 \mathrm{~g} / \mathrm{mL}$.

\section{Measurement of blood parameters}

For determination of heme biosynthesis, the parameters investigated were serum $\delta$-ALAD, EPP, and heme concentrations. This was performed by means of the ELISA assay in the GAKI laboratory, Diponegoro University, Semarang, for all experimental animals of the control and treatment groups on the last day of the thirteenth week.

\section{Data analysis}

Differences in $\delta$-ALAD concentrations between control and treatment groups were analyzed by the Kruskal-Wallis test, whereas differences in EPP and heme concentrations were tested by one way ANOVA, followed by Bonferroni's test.

\section{Ethical clearance}

We conducted this study after receiving ethical clearance from the Ethics Commission, Faculty of Medicine, Diponegoro University/DR. Kariadi Hospital, Semarang, under No. 339/EC/ FK/RSDK/2012. The Head of the Integrated Research and Testing Laboratory, Gadjah Mada University, Yogyakarta, permitted the study to be carried out after having received communications regarding the ethical clearance.

\section{RESULTS}

Improvement of heme biosynthesis was determined from $\delta$-ALAD, EPP, and heme concentrations. The concentrations of $\delta$-ALAD and EPP were decreased with zinc supplementation, in comparison with the control group, whereas the heme concentrations were increased. The details of the mean differences and statistical test results for $\delta$-ALAD, EPP, and heme concentrations after the thirteenth week by treatment group are presented in Tables 1 and 2 below.

There was a difference in mean $\delta$-ALAD concentrations between control and treatment groups. The highest mean was in the control groups $(0.24 \pm 0.20 \mathrm{ng} / \mathrm{mL})$ and the lowest in the Zinc III treatment group $(0.05 \pm 0.06 \mathrm{ng} /$ $\mathrm{mL})$. The Kruskal-Wallis test did not find any significant differences between control and treatment groups $(\mathrm{p}=0.16)$. 
Table 1. Mean $\delta$-ALAD, EPP, and heme concentrations after the thirteenth week by treatment group

\begin{tabular}{|c|c|c|c|c|c|}
\hline \multirow{2}{*}{ Variable } & \multicolumn{4}{|c|}{ Treatment } & \multirow[b]{2}{*}{$\mathbf{p}$} \\
\hline & Control $(n=7)$ & Zinc I $(n=7)$ & Zinc II $(n=7)$ & Zinc III $(n=7)$ & \\
\hline \&-ALAD (nglmL) & $0.24 \pm 0.20$ & $0.15 \pm 0.15$ & $0.12 \pm 0.11$ & $0.05 \pm 0.06$ & 0.162 \\
\hline $\mathrm{EPP}(\mathrm{ng} / \mathrm{mL})$ & $1.96 \pm 0.50$ & $1.24 \pm 0.24$ & $1.03 \pm 0.05$ & $0.62 \pm 0.16$ & 0.000 \\
\hline Heme $(\mu M)$ & $8.07 \pm 2.64$ & $10.11 \pm 2.27$ & $10.04 \pm 1.65$ & $11.41 \pm 2.58$ & 0.134 \\
\hline
\end{tabular}

There were differences in mean EPP concentrations between the control and treatment groups. The highest mean $(1.96 \pm 0.50 \mathrm{ng} / \mathrm{mL})$ was in the control group without zinc supplementation, and the lowest mean $(0.62 \pm$ $0.16 \mathrm{ng} / \mathrm{mL}$ ) was in the treatment group receiving zinc supplementation at a dose of $0.8 \mathrm{mg}$. ANOVA test results showed significant differences between control and treatment groups $(\mathrm{p}=0.00)$. There was no significant difference in mean heme concentrations ( $\mathrm{p}=0.13$ ).

The results of Bonferroni's muliple comparison test showed significant differences in mean EPP concentrations between the control group versus the Zinc I, Zinc II and Zinc II treatment groups (Table 2).

\section{DISCUSSION}

From the results of this study, there was a reduction in $\delta$-ALAD concentrations in the treatment groups receiving zinc supplementation. However, laboratory investigations showed a downward trend in $\delta$-ALAD concentrations, starting from the control group to the treatment groups of the lead-exposed rats. Higher zinc doses resulted in lower $\delta$-ALAD concentrations

Table 2. Results of Bonferroni's test for EPP after thirteenth week by treatment group

\begin{tabular}{lcc}
\hline $\begin{array}{c}\text { Erythrocyte } \\
\text { protop orp hyr in/EPP }\end{array}$ & $\begin{array}{c}\text { Mean } \\
\text { differ ences } \\
\text { (mg/mL) }\end{array}$ & p \\
\hline Control vs Zinc I & 0.69 & 0.03 \\
Control vs Zinc II & 0.90 & 0.00 \\
Control vs Zinc II & 1.32 & 0.00 \\
ZincI vs Zinc II & 0.20 & 1.00 \\
ZincI vs Zinc III & 0.62 & 0.10 \\
ZincII vs Zinc III & 0.41 & 0.14 \\
\hline
\end{tabular}

in the lead-exposed rats. Lead can inhibit precursors of heme biosynthesis, such as $\delta$ ALAD. The activity of $\delta$-ALAD is disturbed by lead, causing $\delta$-ALA not to be converted into porphobilinogen so that there is an increase in $\delta$-ALAD concentrations. These changes due to lead exposure are acute or toxic. Further studies are needed on the possibility of compensatory mechanisms of the body in the form of increases in $\delta$-ALAD concentrations to convert $\delta$-ALA into porphobilinogen. The ELISA assay used in the present study was capable of measuring all $\delta$ ALAD concentrations, both those from lead inhibition as well as those excreted by the body as a compensatory mechanism, so that $\delta$-ALAD concentrations increased after lead exposure. Lead exposure of rats that have previously received zinc supplementation resulted in decreased $\delta$-ALAD concentrations. This may be because the metallothioneins that are formed will bind the lead, while the metallothionein-bound zinc is released and activates $\delta$-ALAD. Because of activation, $\delta$-ALAD again functions normally, being capable of converting $\delta$-ALA into porphobilinogen, so that the body does no longer increase $\delta$-ALAD concentrations in compensation, so decreasing its concentrations. This $\delta$-ALAD activation improves heme biosynthesis. Several studies support our results stating that lead is capable of increasing $\delta$-ALAD and some of these studies have been conducted on zinc and $\delta$-ALAD. ${ }^{(14-16)}$

The EPP concentrations were reduced in the treatment groups receiving zinc supplementation in comparison with the control group that were only exposed to lead. This may be explained by the fact that the last enzyme to be inhibited by lead in heme biosynthesis is ferrochelatase. This 
enzyme is present in the mitochondria and plays a role in the complexing of $\mathrm{Fe}$ to the protoporphyrin ring. ${ }^{(17)}$ Inhibition of ferrochelatase increases erythrocyte protoporphyrin/EPP. Several studies have found evidence for a correlation between lead exposure and erythrocyte protoporphyrin. Lowry et al. ${ }^{(18)}$ studied the effects of lead exposure on cytochrome 450 (CYP) and found that lowintensity lead exposure had no effects on cytochrome 450 metabolism, but affected several pathways in hemoglobin synthesis. The EPP concentrations increased on exposure to lead of $>10 \mu \mathrm{g} / \mathrm{dl}$. EPP concentrations increased significantly in the exposed group (battery factory workers) as compared with controls. ${ }^{(15)}$ Shah F et al. ${ }^{(2)}$ studied blood lead levels and the prevalence of iron deficiency anemia in children aged between 1 to 5 years, and found that children with severe iron deficiency anemia had higher lead levels in the blood as compared with children with mild iron deficiency anemia. There was a significant negative correlation between blood lead levels and iron deficiency anemia. These results are similar to those of zinc supplementation, but are based on different mechanisms. Iron complexes with porphyrin to form heme, whereas zinc supplementation competes with lead for metallothionein sulfhydryl groups so that there is no accumulation of EPP.

In the present study, heme concentrations were low after lead exposure without zinc supplementation, whereas heme concentrations increased, although not significantly, after lead exposure with zinc supplementation. This proves that zinc supplementation is capable of increasing heme synthesis in lead-exposed rats. To increase heme concentrations significantly in lead-exposed rats, the zinc supplementation dose should be increased. Zinc is an important micromineral in biological processes in the body. The role of zinc in heme biosynthesis is with regard to ALAD, which is a zinc-containing enzyme that plays a role in catalyzing the condensation of two molecules of ALA into two molecules of water and one molecule of porphobilinogen (PBG). Zinc deficiency inhibits this reaction and influences heme formation. ${ }^{(3)}$ In heme synthesis, the second enzyme that plays a role is $\delta$-ALAD. This enzyme is exceedingly rich in sulfhydryl groups with a stronger affinity for lead in comparison with zinc. Full enzyme activity requires intact or complete sulfhydryl groups and one zinc atom for each subunit. Enzyme activity is inhibited if the zinc is replaced by other metals, such as lead. ${ }^{(3)}$ Addition of zinc may reverse the inhibition of $\delta$-ALAD, but this requires higher zinc concentrations. ${ }^{(14)}$ According to Santosa et al. ${ }^{(12)}$ zinc supplementation may increase metallothioneins that are rich in sulfhydryl groups capable of binding lead, causing no interference with delta $\operatorname{ALAD}^{(3)}$ and no inhibition of heme biosynthesis. Various studies of the effect of lead exposure on heme biosynthesis have supported the results of the present study. Several studies on lead exposure in battery factory workers showed increases in the heme biosynthesis parameters $\delta$-ALAD and EPP, but showed decreases in heme and hemoglobin concentrations. ${ }^{(18)}$ Lead exposure in 30 automobile workers caused increases in $\delta$ ALAD, EPP, porphobilinogen and decreases in heme and hemoglobin concentrations. ${ }^{(19)}$ Heme is an integral part of proteins involved in several electron transport chains for energy renewal that are found in nearly all forms of life. In addition, heme is a cofactor of enzymes, including catalase, peroxidase, cytochrome $\mathrm{P} 450$, and is a part of sensor molecules. ${ }^{(20)}$

One limitation of this study was that the ELISA assay for assessment of $\delta$-ALAD concentrations will measure all forms of the enzyme, and cannot distinguish between leadinhibited and noninhibited forms. The clinical implication of this study is that zinc supplementation has been proved to reduce $\delta$ ALAD and EPP concentrations and to increase heme concentrations, indicating that zinc is capable of repairing heme biosynthesis in rats exposed to lead, so that further studies are necessary to apply these findings to humans. 


\section{CONCLUSION}

Zinc supplementation at doses of $0.4 \mathrm{mg}$ and $0.8 \mathrm{mg}$ significantly improves heme biosynthesis, marked by reduced $\delta$-ALAD and EPP concentratioins and increased heme concentrations.

\section{ACKNOWLEDGMENTS}

We thank the Directorate-General of the Department of Higher Education (DIRJEN DIKTI), Ministry of Education and Culture (Kemendikbud), for the funding of this study.

\section{REFERENCES}

1. Markowitz M. Lead poisoning. In: Behrman RE, Kliegman RM, Jenson HB, editors. Nelson textbook of Pediatrics. $18^{\text {th }}$ ed. Philadelphia: Saunders; 2010.p.2913-7.

2. Shah F, Kazi TG, Afridi HI, et al. Environmental exposure of lead and iron deficit anemia in children age range 1-5 years: a cross sectional study. Sci Total Environ 2010;408:5325-30. doi: 10.1016/j.scitotenv.2010.07.091.

3. Ahamed M, Singh S, Behari JR, et al. Interaction of lead with some essential trace metals in the blood of anemic children from Lucknow, India. Clin Chim Acta 2007;2:92-7.

4. Hamilton WJ, Ledvina PS, Lopez RA, et al. Childhood lead poisoning in Galveston, Texas: background - health effects - hot spots intervention. Version 1. Texas: Baylor College of Medicine; 2007.

5. Manahan SE. Toxicological chemistry and biochemistry. $3^{\text {rd }}$ ed. New York Washington: Lewis Publishers; 2003.

6. World Health Organization. Childhood lead poisoning. Geneva: World Health Organization; 2010.

7. Kabe Y, Ohmori M, Shinouchi K, et al. Porphyrin accumulation in mitochondria is mediated by 2 oxoglutarate carrier. J Biol Chem 2006;281: 31729-35.

8. American Academy of Pediatrics, Committee on Environmental Health. Lead exposure in children: prevention, detection, and management. Pediatrics 2005;16:1036-46.

9. Zuo P, Qu W, Cooper RN, et al. Potential role of a-synuclein metallothionein in lead-induced inclusion body formation. Tox Sci 2009; 111:1008.

10. Lee SM, McLaughlin JN, Frederick DR, et al. Metallothionein-induced zinc partitioning exacerbates hyperoxic acute lung injury. Am J Physiol Lung Cell Mol Physiol 2013;304:35060.

11. Santosa B, Subagio WS, Suromo L, et al. Zinc supplementation dosage variations to metallothionein protein level of Rattus norvegicus. Int J Sci Eng 2013;5:15-7.

12. Santosa B, Subagio HW, Suromo L, et al. Zinc supplementation decreases basophilic stippling in rats exposed to lead. Univ Med 2014;33:118.

13. Krêzel A, Hao Q, Maret W. The zinc/thiolate redox biochemistry of metallothionein and the control of zinc ion fluctuations in cell signaling. Arch Biochem Biophys 2007;463:188-200.

14. Hariono B. Efek pemberian plumbum (timah hitam) pada tikus putih anorganik (Rattus norvegicus). J Sain Vet 2006;24:125-33.

15. Shaik AP, Jamil K. A study on the ALAD gene polymorphisms associated with lead exposure. Toxicol Ind Health 2008;24:501-06.

16. Yang Y, Wu J, Sun P. Effects of deltaaminolevulinic acid dehydratase polymorphisms on susceptibility to lead in Han subjects from Southwestern China. Int J Environ Res Public Health 2012;9:2326-38.

17. Atamna H, Killilea DW, Killilea AN, et al. Heme deficiency may be a factor in the mitochondrial and neuronal decay of aging. PNAS 2002;99: 14807-12.

18. Lowry JA, Pearce RE, Gaedigk A, et al. Lead and its effects on cytochromes P450. J Drug Metab Toxicol 2012;5:1-4.

19. Dongre NN, Suryakar AN, Patil AJ, et al. Biochemical effects of lead exposure on systolic $\&$ diastolic blood pressure, heme biosynthesis and hematological parameters in automobile workers of North Karnataka (India). Ind J Clin Biochem 2011;26:400-6.

20. Heinemann IU, Jahn M, Jahn D. The biochemistry of heme biosynthesis. Arch Biochem Biophys 2008;474:238-51. 